\title{
Investigations on the relationships between algal blooms and bacterial populations in the Schlei Fjord (western Baltic Sea)
}

\author{
M. RIEPER \\ Institut für Meereskunde; Kiel, Federal Republic of Germany
}

\begin{abstract}
KURZFASSUNG: Untersuchungen über die Beziehungen zwischen Algenblïten und Bakterienpopulationen in der Schlei (westliche Ostsee). Die Wechselbeziehungen zwischen Algenblüten und Bakterien wurden in der Schlei, einer Förde der westlichen Ostsee, untersucht. Die Wasserblüten, im Frühjahr von Chlorella spec. und im Spätsommer von Microcystis aeruginosa gebildet, werden von Anderungen in den Bakterienpopulationen begleitet. Laborversuche wurden durchgeführt mit den hauptblütenbildenden Algenarten und den dominanten Bakterienarten. Die Ergebnisse zeigen, daß das Wachstum von einigen rotpigmentierten Bakterien (Flavobacterium), die die Wasserblüte von Chlorella begleiten, durch Stoffe, die von den Algen in der logarithmischen Wachstumsphase in das Medium abgegeben werden, gefördert wird. Microcystis aeruginosa wird von mindestens zwei chitinabbauenden Bakterienarten (darunter Pseudomonas spec.) begleitet. Die ökologischen Zusammenhänge werden diskutiert.
\end{abstract}

\section{INTRODUCTION}

This present work was undertaken in order to investigate the relationships between phytoplankton and bacteria in the Schlei, a fjord of the western Baltic Sea. The Schlei has been a focal point of interest not only for the abundance of fish to be found in its waters but also increasingly for its value as a vacation area. A summary of the most important and characteristic features of the Schlei can be found in NELLEN \& Rheinheimer (1970a) and KöNIG (1970). In brief, this fjord is about $40 \mathrm{~km}$ long (Fig. 1), very narrow and shallow, and in most places only several meters deep. The salinity of the water decreases from approximately $21 \%$ at the mouth to $5 \%$ or less at Schleswig, but may undergo strong fluctuations. Since the exchange with cleaner Baltic Sea water is limited, nutrients in the form of household and industrial wastes as well as fertilizers from the cultivated land areas nearby reach a higher concentration in the Schlei than in the Baltic Sea. These factors have contributed to an increased eutrophication of the Schlei (see Rheinhermer et al., 1970). From early spring, throughout the summer and often well into the autumn, the waters of the Schlei are colored a deep green due to the presence of numerous, mostly single-celled algae. Chlorella sp. (Chlorophyceae) forms a water bloom from February or March until 
June, while the Cyanophyceae, consisting mainly of Microcystis aeruginosa, dominate in the late summer.

During investigations on the bacterial distribution in the Schlei, it was noted by RHEINHEIMER (1970c) that in the summer, particularly during the phytoplankton blooms, relatively low numbers of saprophytic bacteria were found and, in general, seemed to develop more slowly than usual. This decrease in the saprophyte numbers during the summer was observed to occur in the native marine and brackish water populations as well as in the numbers of freshwater and terrestrial bacteria which mostly enter the Schlei via drainage channels, small rivers and with wastewater. The bacteria of terrestrial origin often showed a greater decrease at this time than the native forms. Investigations on the occurrence of Agrobacterium species (Rhizobiaceae), which may play a large role in the Schlei during certain times of the year (AHRENs, 1969), also showed that these are at a minimum in the summer. The yearly cycle of Agrobacterium species showed that this minimum coincided with the mass development of phytoplankton, particularly that of the Cyanophyceae. While other factors such as salinity, temperature and amount of nutrients have a decided influence on the distribution and composition of the bacterial flora, the possibility that many bacteria in the Schlei were suppressed in their development by antibiotic substances secreted by the algae during a water bloom could not be discounted (RHEINHEIMER, $1970 \mathrm{e})$.

The results reported here should provide answers to the question as to whether or not the phytoplankton blooms have a harmful effect on bacterial populations in the Schlei, and also supplement our knowledge of the relationships between these microorganisms in general.

This work represents part of a dissertation (RIEPER, 1975) which was carried out in the Institut für Meereskunde, Universität Kiel, under the direction of Prof. Dr. G. RHEINHEIMER.

\section{MATERIALS AND METHODS}

Between May 1972 and December 1973 twenty monthly profile voyages were made into the Schlei fjord; five supplementary voyages in 1974 were also made, at bimonthly intervals. In addition to the numbers of saprophytic bacteria (viable counts) and the phytoplankton numbers, other biotic as well as abiotic factors which could influence the distribution of these microorganisms were also determined: the occurrence of yeasts, the coli counts, salinity, temperature and $\mathrm{pH}$ of the water, ammonia, nitrate, nitrite and phosphate content, and amount of oxygen in the water. Details of the methods which were used can be found in RHEINHEIMER (1970a-d).

Samples for study were taken at a depth of $1 \mathrm{~m}$ at the following stations (see Fig. 1): (1) Tonne Schlei Olpenitz; (2) Maasholm; (3) Kappeln; (4) Bienebek; (5) Königsburg; (6) Große Breite; (7) Schleswig. The samples used for determination of the bacteria and phytoplankton numbers were handled immediately on board the research cutter "Hermann Wattenberg"; those for analysis of inorganic $\mathrm{N}$ - and $\mathrm{P}$-compounds were kept cool and frozen at $-20^{\circ} \mathrm{C}$ upon return to the laboratory. 
With the data obtained from the profile voyages, it was possible to give a detailed description of the study area including the changes taking place within the algae and bacteria populations throughout the year. In order to explain the relationship of these microorganisms to one another, it was necessary to isolate them and obtain pure cultures for laboratory experiments. The two main bloom-forming algae, Chlorella sp.

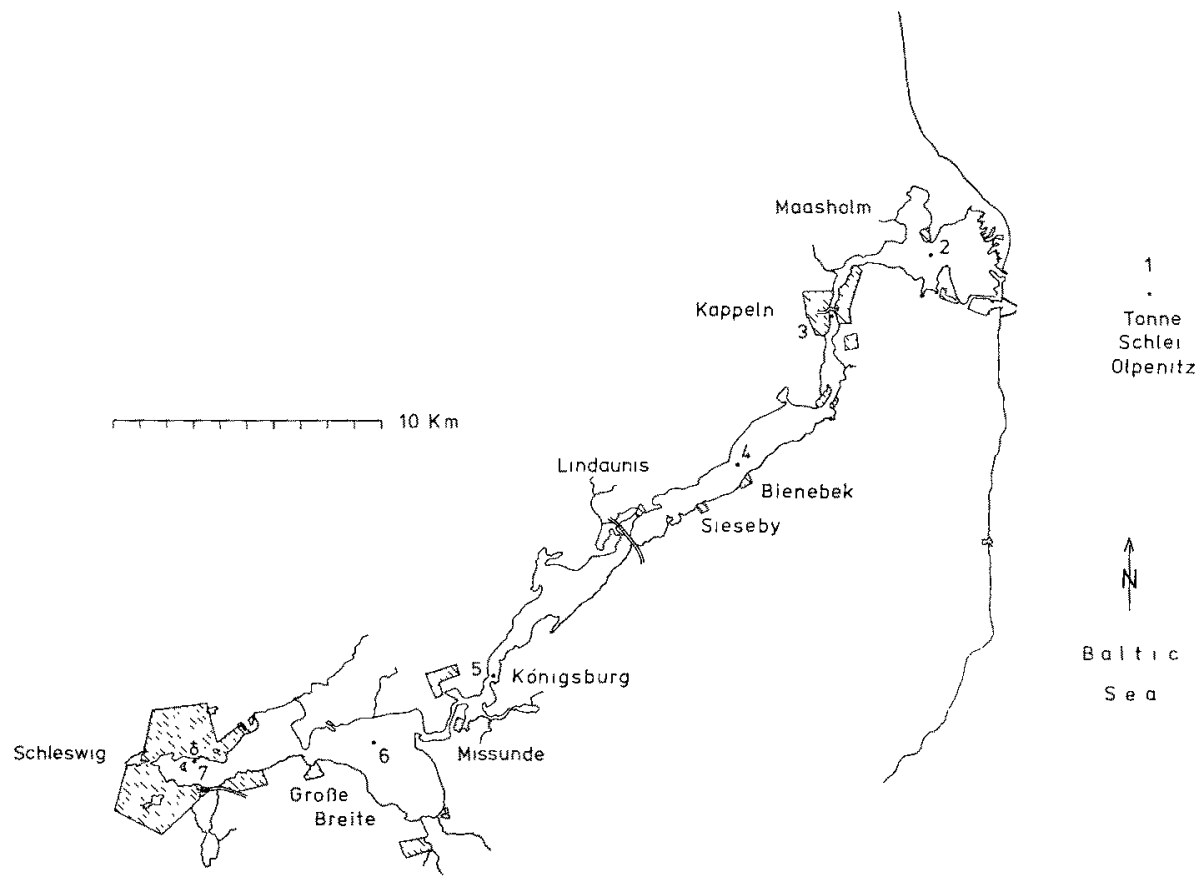

Fig. 1: Area of the Schlei Fjord

and Microcystis aeruginosa, were chosen for the studies. Among the bacteria, pigmented forms which were common and easily recognizable were isolated. Special attention was given to native brackish water forms which could grow well at a salinity corresponding to that of the inner Schlei area $(2.5$ to $10 \% \mathrm{~S})$ where the water blooms occurred.

The algae were isolated during water blooms in the Schlei between 1972 and 1973 (see KocH, 1965). Stock algae cultures were maintained on agar plates prepared with modified Zehnder's solution (ZEHNDER, unpublished, in STAUB, 1961; modified further by MefFert, 1973a) with 1-1.5\% Difco Bacto-agar. The agar and mineral solutions were autoclaved separately (AlLEN, 1968). Cblorella sp. cultures were axenic; Microcystis was unialgal but not bacteria-free.

The algae cultures were maintained at $20^{\circ} \mathrm{C}$ illuminated with 2 fluorescent lamps, one Philips Warmtone de Luxe and one Philips Cool White, with 2000 lux measured on a Luxmeter. The light and dark cycles were 14 and 10 hours respectively. Liquid stock cultures were prepared from agar plates shortly before the start of an experiment. 
Bacteria used in the experiments were either isolated from the Schlei or obtained from the Institut für Meereskunde collection. The strains were maintained on agar slants containing ZoBell $2216 \mathrm{E}$ agar prepared with a seawater-distilled water mixture for a final salinity of $8.3 \%$. Before the start of an experiment, the bacteria were transferred to liquid media and diluted with a seawater-distilled water mixture (S $8.3 \%$ ) before transferring into the experimental flasks.

Experiments were carried out in $300 \mathrm{ml}$ Erlenmeyer flasks containing 100 to $150 \mathrm{ml}$ of modified Zehnder's solution. This solution was prepared with 1 part Schlei water to 4 parts dist. water which gave a salinity of $2.5 \%$. $\mathrm{NaCl}$ was added when higher salinities were required in the experiments. The Erlenmeyer flasks were not shaken or aerated during the course of an experiment, but were mixed well before each sampling. The illumination was the same as that described above for the algae cultures. Under these experimental conditions both the algae and bacteria populations reached the end of their exponential growth phase after 7-10 days. For this reason, experiments were seldom longer than 2 weeks.

For determining the algae concentration, a sample of the test solution was filtered through a $0.45 \mu \mathrm{m}$ membrane filter (Sartorius), dried, rendered transparent with immersion oil and examined under the microscope. Calculation of the cell numbers per $\mathrm{ml}$ was made according to the formula described by Rodina (1972). The bacteria numbers were counted on ZoBell agar plates (S 8.3\% after dilution; three different dilutions were prepared in duplicate for each sample. The colonies were counted after 14 days incubation at $20^{\circ} \mathrm{C}$.

Sterile filtrates were prepared from Microcystis aeruginosa and from one of the test bacteria strains (51; see Table 1), in order to determine if these microorganisms secreted substances with antibiotic activity into the culture medium. The algae were first pre-filtered through filter paper (Schleicher and Schïll Selecta Faltenfilter Nr. $595 \%, \varnothing 32 \mathrm{~cm}$ ) and a $0.45 \mu \mathrm{m}$ membrane filter, before final filtration through a $0.2 \mu \mathrm{m}$ sintered glass filter. The culture fluid from the bacteria was filtered only through the membrane and sintered glass filters.

\section{RESULTS}

\section{Investigations in the Schlei}

The results of the monthly profile voyages to the Schlei have been reported in detail by RIEPER (1975). Since, for the most part, they are in agreement with those found by RHeINHeImer (1970a-f) during earlier investigations in the Schlei, these results will be presented here only briefly.

The seasonal variations in the content of ammonia- $N$, nitrate- $N$, nitrite- $N$ and phosphate-P are shown in Figure 2. The values represent the averages for the stations 3 to 7 inclusive over a period of $2 \frac{1}{2}$ years, and may be considered as characteristic for the Schlei.

Of special interest are the seasonal variations in the numbers of saprophytic bacteria (Fig. 3). The highest counts are found on ZoBell seawater medium with a 
salinity range of 8.3 to $25 \%$. During earlier investigations in the Schlei, RHEINHEIMER (1970c) found that the highest numbers of saprophytic bacteria generally occurred in the winter from November to January, and again in the spring from April to June. A minimum occurred in the summer during the months from July through September.

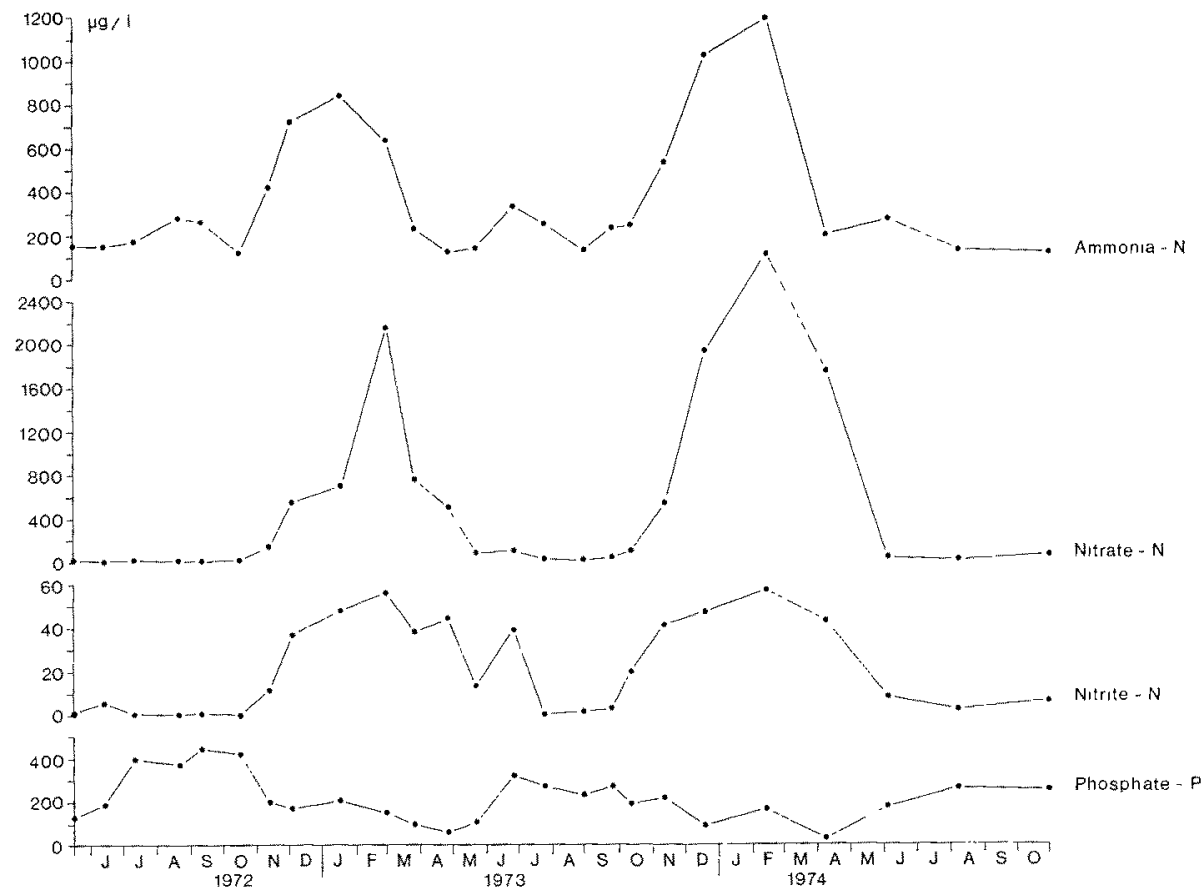

Fig. 2: Average concentrations of ammonia- $\mathrm{N}$, nitrate- $\mathrm{N}$, nitrite- $\mathrm{N}$ and phosphate- $\mathrm{P}$ for the stations between Kappeln (3) and Schleswig (7)

This tendency may also be seen in Figure 3, although for reasons which are unknown, the values on seawater agar (S 8.3-25\%) from June to August 1973 are unusually high, and are often 3 to 4 times greater than the corresponding values for 1972 and 1974.

The highest counts regardless of the season can usually be found in the inner Schlei, particularly at stations 6 and 7. A second, smaller maximum may occasionally also be found at station 3 (Kappeln), the second largest city along this fjord. The reasons for the higher concentrations of bacteria, especially in the inner Schlei, may be found in the greater amounts of nutrients from household and industrial wastes; the reduced salinity of the water here as well as little exchange with cleaner Baltic Sea water would also favor the accumulation of freshwater and terrestrial bacteria in this area.

The percentage of pigmented bacteria also shows seasonal fluctuations. Particularly in the spring and early summer, up to $40 \%$ of the saprophyte numbers are 
red pigmented bacteria, which constitute a fairly homogeneous population. Figure 4 shows the percentage of red bacteria occurring at station 6 , where often the highest saprophyte counts as well as phytoplankton concentrations could be found. The highest percentages occur during the spring Chlorella water bloom and are lowest in the summer when the Cyanophyceae predominate (see also Fig. 5).

It should be mentioned here that the saprophyte counts obtained from samples of Schlei water by means of the poured-plate method represent only a fraction of the total number of bacteria found by direct counting methods with the microscope

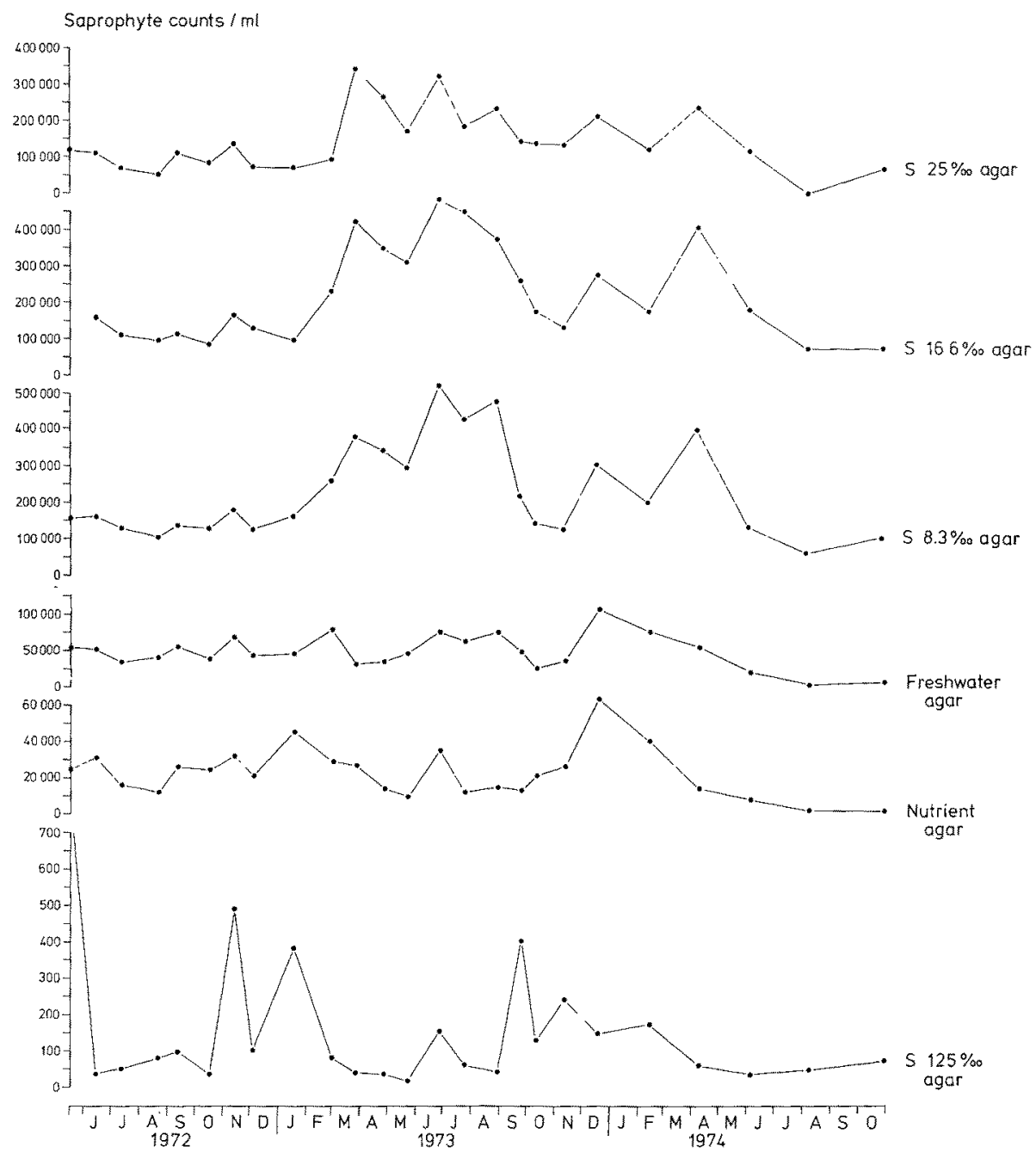

Fig. 3: Average saprophyte counts on six different agar media for stations 3 to 7 from May 1972 to October 1974 
(RHeinHeimer, 1971). E. g., the plate counts from stations 3 to 7 in August 1974 were generally under 100000 per $\mathrm{ml}$, whereas ZIMmERMANN (personal communication) found values from 20 to 30 million per $\mathrm{ml}$ with the method of fluorescence microscopy. The poured-plate method was used in the investigations here, however, because of its sensitivity, the reproducibility of the results as well as the ease and speed with which a large number of samples could be analyzed. Moreover, saprophytic bacteria in par-

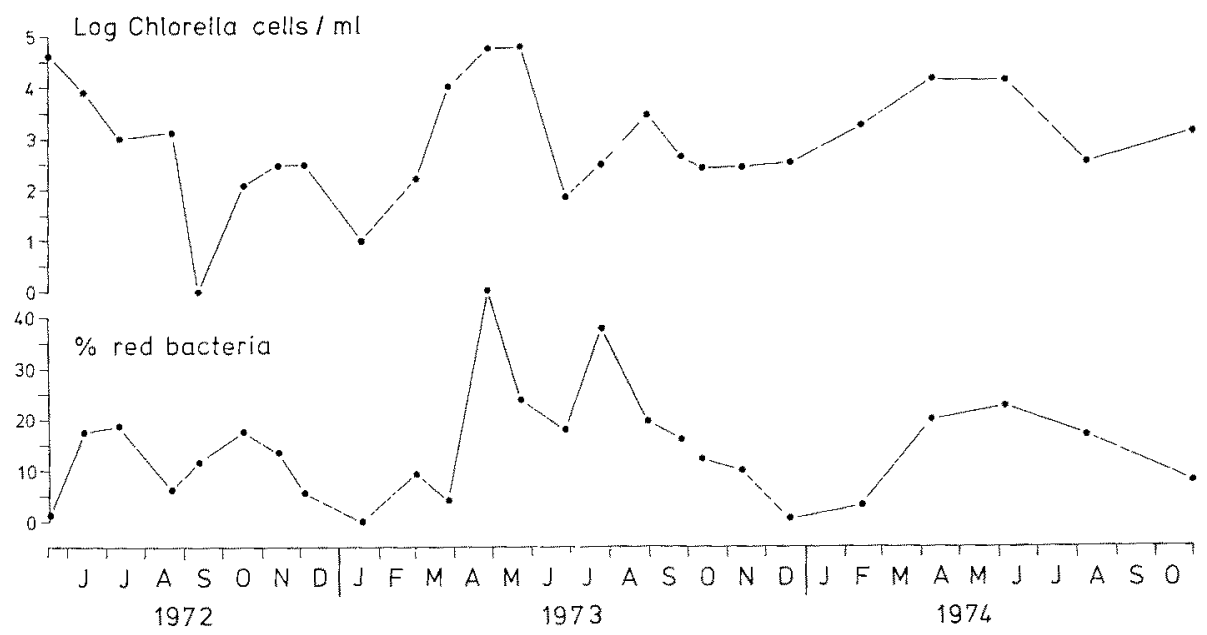

Fig. 4: Comparison of the percentage of red pigmented bacteria with the concentration of Chlorella sp. occurring at station 6

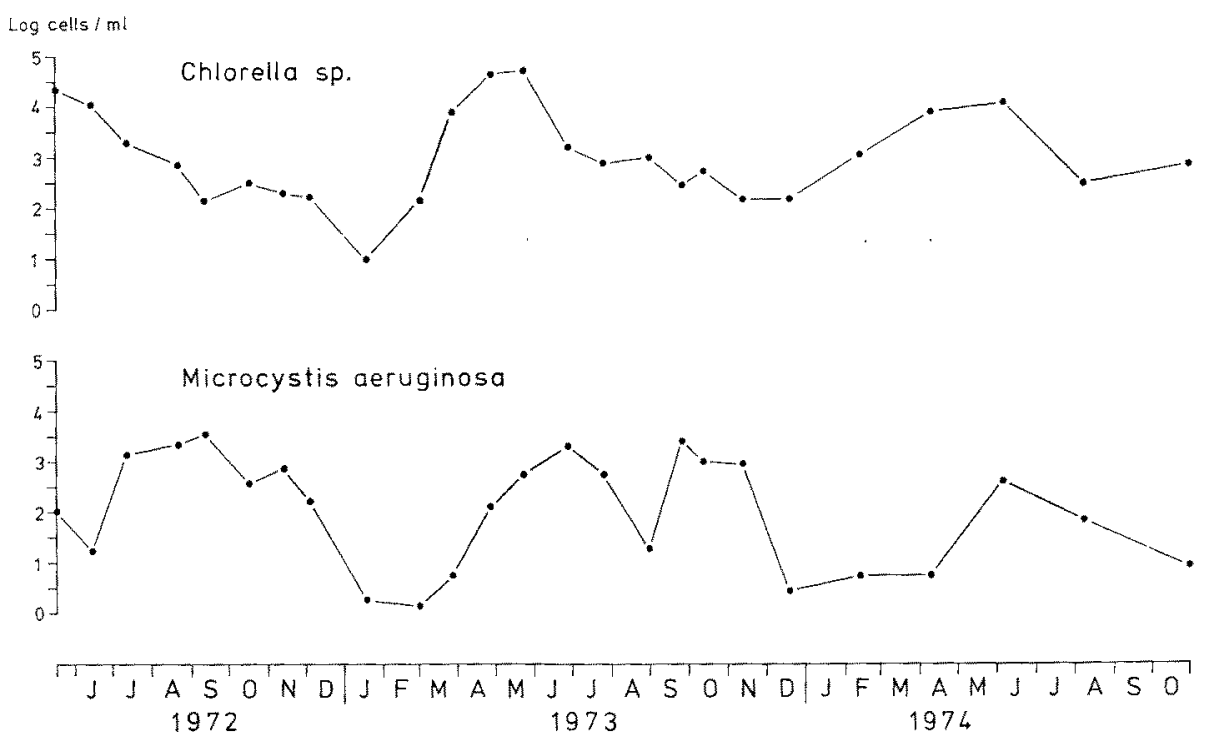

Fig. 5: Average algae cell counts per $\mathrm{ml}$ for the stations between Kappeln (3) and Schleswig (7) 
ticular react rapidly to changes in their environment, e. $g_{+}$, in the amount of nutrients present. Changes occurring within a saprophytic bacteria population are more easily observed on agar plates - such as those described here in connection with the different water blooms - but would not be noticeable with the direct counting methods.

The highest phytoplankton counts are found in the inner Schlei area between stations 4 and 7 where the salinity is lowest (usually between 5 and 10\%) and the concentration of inorganic nitrate and phosphate compounds is greatest (compared to values in the western Baltic Sea). The numbers of phytoplankton undergo large

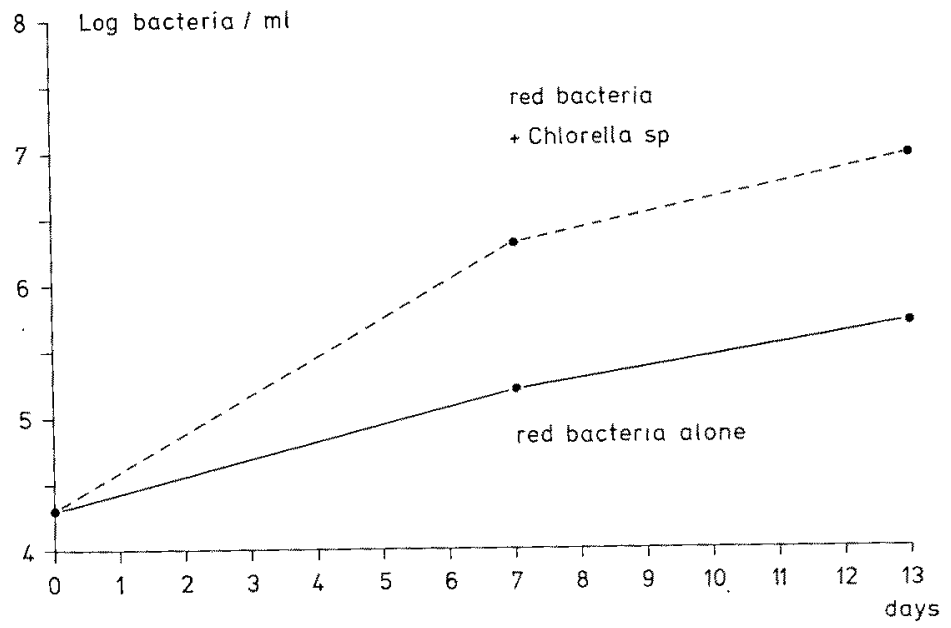

Fig. 6: Red bacteria cultivated alone and together with Chlorella sp. $\left(20^{\circ} \mathrm{C}\right)$

seasonal variations. The spring water bloom is nearly a monoculture of Chlorella sp., minute single-celled algae 2-4 $\mu \mathrm{m}$, which may grow equally well in freshwater and in brackish water media. The second major bloom, occurring from August to October, is composed of various Cyanophyceae with Microcystis aeruginosa as the dominant species. This agrees with results regarding the distribution of phytoplankton in the Schlei found by Jürgens (unpublished, in Schiemann, 1974). The blooms are separate although some overlapping does occur (Fig. 5).

\section{Results of laboratory experiments}

Among the bacteria which were tested was a red pigmented form which was especially common in the spring and early summer (Fig. 4). The results presented in Figure 6 show that these red bacteria grow better in the presence of Chlorella than when cultivated alone. The effect was slightly more pronounced at higher temperatures. The enhancement of bacterial growth continued after the algae reached the end of their exponential growth phase. Onset of the stationary phase of Chlorella took place after approximately ten days, under the experimental conditions described. 
Other strains of Schlei bacteria cultivated with Cblorella sp. were not influenced by the presence of these algae. An inhibitory effect on the growth of Escherichia coli was noted, however (Fig. 7). The suppression of E. coli began toward the end of the algal exponential phase of growth, and was greatest during the stationary phase.

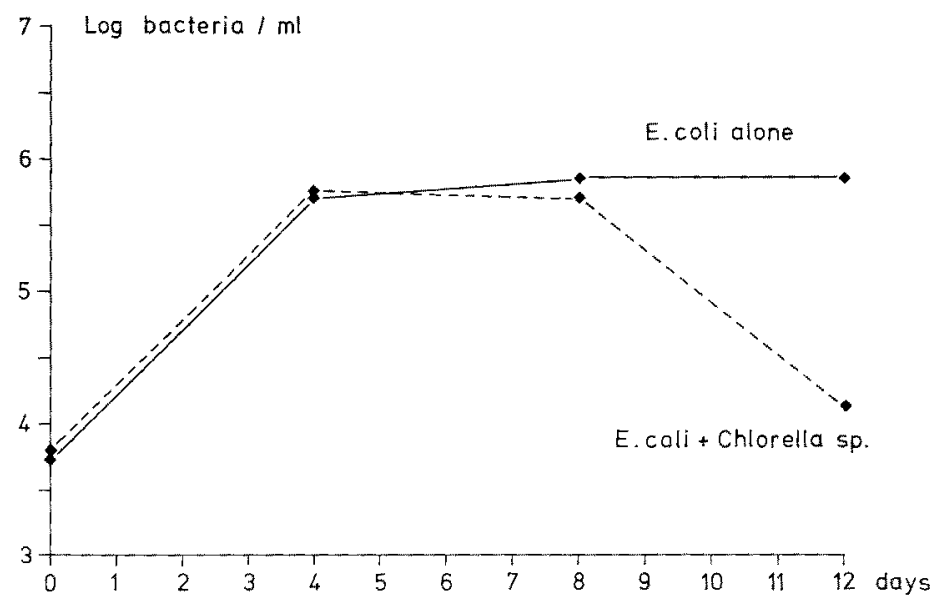

Fig. 7: Escherichia coli cultivated alone and together with Chlorella sp. $\left(20^{\circ} \mathrm{C}\right)$

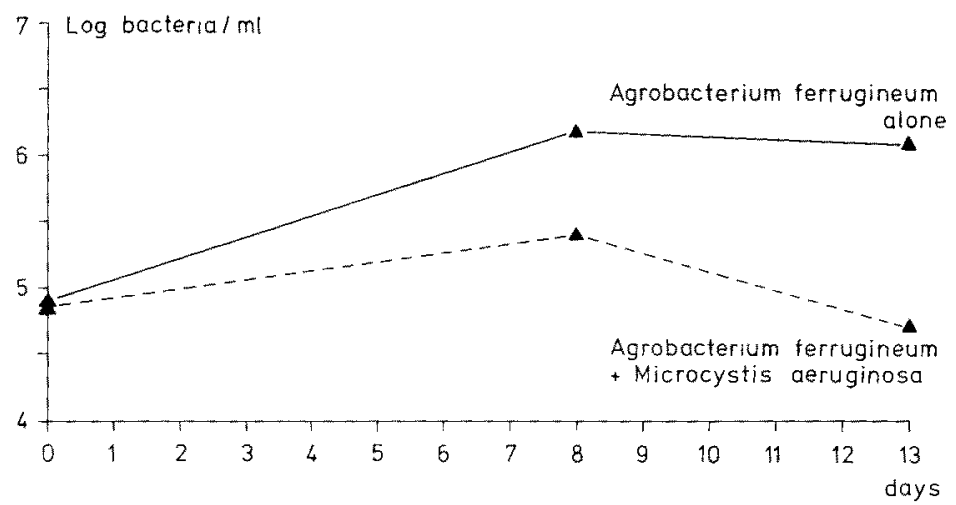

Fig. 8: Agrobacterium ferruginetum cultivated alone (continuous line) and together with a nonaxenic culture of Microcystis aeruginosa (dotted line) $\left(20^{\circ} \mathrm{C}\right.$ )

No significant differences were observed in the growth curves of axenic cultures of Chlorella sp., and those to which various strains of bacteria were added. Microscopic examination of the cultures during and at the end of the experiments showed that the bacteria did not colonize the algae at any time.

The experiments described above were also carried out with Microcystis aeruginosa. When cultivated together with Microcystis, the red bacteria, Agrobacterium ferrugineum and $E$. coli were suppressed in their growth as compared to controls with- 
out algae. As shown in Figure 8, the suppression begins immediately. In all experiments described here, only young actively growing cultures of algae were used. As with Cblorella sp., the growth rate of Microcystis was not affected by any of the bacteria strains tested.

Since Microcystis cultures were non-axenic, a possible inhibitory influence of the associated bacteria on the test strains could not be excluded. Therefore the experiments were repeated, using the dominant bacteria species inhabiting the Microcystis slime layer instead of the algae (strain 51 ). These bacteria are highly motile rods having a salinity optimum of $15 \%$; other charakteristics are listed in Table 1 . On agar plates

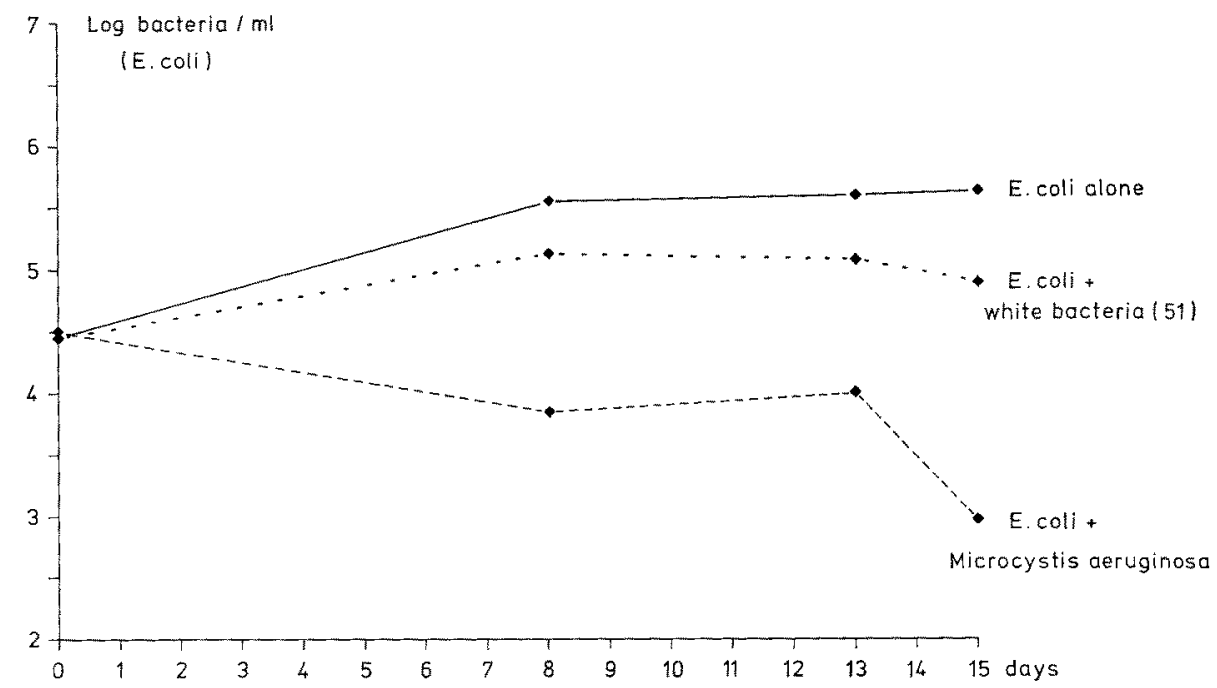

Fig. 9: Escherichia coli cultivated alone, with a non-axenic culture of Microcystis aeruginosa, and with the dominant bacteria strain (51) from the Microcystis slime layer $\left(20^{\circ} \mathrm{C}\right)$

the colonies formed are large, translucent white and develop rapidly at room temperature. Results showed that this strain had a decided inhibitory influence on most of the test bacteria isolated from the Schlei. The suppression of $E$. coli, however, was greater in a culture medium containing the contaminated Microcystis, than with a pure strain of the white bacteria (Fig. 9). In both cases the suppression begins immediately. It was concluded that the inhibitory effect on $E$. coli due to the presence of Microcystis aeruginosa may also be attributed, in part, to the bacteria associated with these algae.

It has already been noted that there is usually a decrease in the saprophytic bacteria counts in the Schlei during the summer months. Large white or colorless colonies are more frequently seen on agar plates prepared from water samples taken at this time. These colonies develop rapidly and suppress the growth of other bacteria on the plates. In particular the pigmented bacteria such as red and yellow forms as well as brown species appear small and pale when they occur near the large white colonies. Often other bacteria fail to develop at all, within a certain radius of the white colonies. 
Could the white strain 51 isolated from the Microcystis slime layer have a general inhibitory effect on the common pigmented Schlei bacteria, as has already been shown with $E$. coli?

Accordingly, various pigmented bacteria were cultivated alone and together with strain 51 . The first test series was carried out in liquid culture media; bacteria counts were then made on agar plates prepared from the test solutions. A second series of experiments was carried out on agar plates only, onto which the strains to be tested were directly inoculated. The results from both series of experiments showed clearly that strain 51 could suppress the growth of most pigmented bacteria isolated from the Schlei. Of particular interest was the effect on the common red bacteria (strain 8a). Figure 10 demonstrates the growth rate of these red bacteria cultivated alone and with

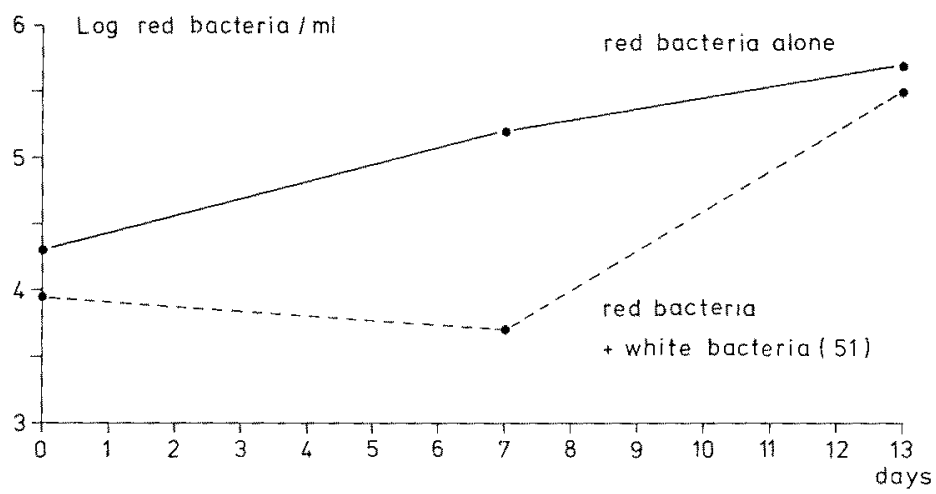

Fig. 10: Red bacteria (strain 8a) cultivated alone and together with white bacteria (strain 51) $\left(20^{\circ} \mathrm{C}\right)$

strain 51 in liquid media at $20^{\circ} \mathrm{C}$ (the results at $10^{\circ} \mathrm{C}$ are very similar). It can be seen that the suppression begins immediately. The red bacteria are suppressed on the agar plates already at the start of the experiment: the initial concentration of red bacteria in test flasks with strain 51 was the same as that in the controls, yet there is already a noticeable difference in the counts at the start.

Noteworthy is the fact that the red bacteria are only suppressed while strain 51 is in the exponential phase of growth. This occurs up to the seventh day under the experimental conditions described. From this point on, the red bacteria recover rapidly until they are nearly as numerous as the controls. The growth of the white bacteria is slightly enhanced by the presence of the red bacteria. Further experiments such as these were carried out, in which the red bacteria outnumbered the whites by a factor of ten at the start of the experiment. This did not essentially alter the shape of the curve represented in Figure 10. Even a relatively small number of white colonies can still inhibit the growth of many red colonies.

In addition to strain 51, another transparent white bacterium species was isolated from the Schlei and tested for antibiotic-like activity. This species, strain 37, also formed large white colonies on agar plates prepared from samples of water taken during a Microcystis bloom. Tests showed that this strain was able to suppress the 
growth of pigmented Schlei bacteria (on agar plates) which were also inhibited by strain 51. Those tested included yellow, red and brown bacteria (strain 14, 8a and 13 respectively). A list of the properties of all strains tested is found in Table 1.

Bacteria which were not suppressed by either 37 or 51 were an extreme halotolerant odhre-colored form (20), an orange strain (35) and, surprisingly, E. coli. It has already been shown in Figure 9 that $E$. coli in liquid media was suppressed by strain 51. There was, however, no evidence of inhibition when these bacteria were inoculated simultaneously onto agar plates.

Table 1

Characteristics of bacteria isolated from the Schlei

\begin{tabular}{|c|c|c|c|c|c|c|c|}
\hline Bacteria strain & $8 a$ & 13 & 14 & 20 & 35 & 37 & 51 \\
\hline Pigmentation & red & brown & yellow & yel.ochre & orange & white & white \\
\hline Gram-stain & - & - & - & + & - & 一 & - \\
\hline Motility & - & + & - & + & - & - & + \\
\hline Salinity optimum (\%o) & 15 & $10-15$ & 15 & 10 & 25 & 15 & 20 \\
\hline Temperature optimum $\left({ }^{\circ} \mathrm{C}\right)$ & 35 & 30 & 24 & 27 & 32 & 20 & 33 \\
\hline \multicolumn{8}{|l|}{ Acid in peptone- } \\
\hline water base with: & & & & & & & \\
\hline Fructose & + & \pm & \pm & + & - & + & + \\
\hline Galactose & + & + & \pm & + & + & + & \pm \\
\hline Glucose & + & + & $(+)$ & + & $(+)$ & + & $\mp$ \\
\hline Maltose & + & + & \pm & + & $(+)$ & + & + \\
\hline Lactose & + & \pm & \pm & + & + & + & \pm \\
\hline Saccharose & + & $\mp$ & \pm & + & + & + & $\mp$ \\
\hline Glycerin & + & \pm & - & + & $(+)$ & + & \pm \\
\hline Mannitol & + & \pm & \pm & + & - & + & 二 \\
\hline $\begin{array}{l}\text { Reducing sugars } \\
\text { from alginate }\end{array}$ & + & + & + & + & + & - & + \\
\hline Indole production & - & - & - & - & - & + & - \\
\hline Methyl-red test & - & - & - & + & - & + & - \\
\hline Voges-Proskauer & - & - & - & - & - & - & -. \\
\hline Kovacs oxidase & - & $(-) ?$ & - & - & - & + & + \\
\hline Catalase prod. & + & $(+)$ & + & + & + & + & + \\
\hline Starch hydrol. & + & $(+)$ & - & + & + & + & + \\
\hline Chitin hydrol. & - & -1 & - & - & - & + & + \\
\hline $\mathrm{H}_{2} \mathrm{~S}$ from cystein & $\overline{(+)}$ & $\overrightarrow{+}$ & - & $(+)$ & $\bar{t}$ & + & + \\
\hline \multicolumn{8}{|l|}{ Nitrate reduction: } \\
\hline nitrite. & - & $(+)$ & - & - & - & + & - \\
\hline ammonia & $(+)$ & $(+)$ & + & $(+)$ & $(+)$ & + & $(+)$ \\
\hline gas & - & - & $一$ & - & - & - & - \\
\hline $\mathrm{NH}_{3}$ from peptone & - & - & - & - & - & + & + \\
\hline Gelatin liquef. & - & + & + & + & + & + & + \\
\hline
\end{tabular}

The question was then considered as to whether the suppression could be due to an antibiotic-like substance secreted by the white bacteria. Accordingly, a sterile filtrate was prepared from the culture solution of strain 51 during exponential growth. Test tubes containing $5 \mathrm{ml}$ of the filtrate were inoculated with a small amount of the bacteria to be tested. After an incubation period of several days, a strong turbidity was noted in all test tubes with the filtrate as well as in the controls. The bacteria tested 
included the red, yellow, orange and brown forms, most of which were inhibited by the presence of strain 51 on agar plates. Similar tests were also carried out using a sterile filtrate prepared from non-axenic Microcystis aeruginosa cultures in the exponential phase of growth as well as from stagnating cultures. The results were the same as above: all pigmented bacteria were able to grow in the culture filtrates from Microcystis regardless of the age of the algae when filtered.

It was concluded therefore, that neither strain 51 nor the algae themselves secrete antibiotic substances which can suppress the growth of the pigmented bacteria. The suppression observed on agar plates is the result of competition for nutrients, whereby the rapidly developing white strains have the advantage.

Further experiments were carried out in order to determine if other Schlei bacteria, apart from the two white strains, could influence one another. Various species were cultivated together in liquid media and plate counts were made from sample aliquots in the usual manner. Results showed that the red bacteria are also inhibited by Escherichia coli. Again, as in experiments with strain 51, the inhibition took place only on the agar plates but not in the culture solution. At higher dilutions with correspondingly lower numbers of $E$. coli colonies on the plates, more red colonies were able to develop than at the lower dilutions. The growth of $E$. coli was enhanced by the presence of the red bacteria.

\section{DISCUSSION}

The problem of the relationship between bacteria and algae is expecially relevant with the emphasis on aquatic ecology today. As to the nature of this relationship, there is no simple formula. Some bacteria may benefit from the algae and vice versa. They may also adversely affect one another by the secretion of substances with antibiotic activity.

The stimulation of bacterial growth by algae seems to be quite common. It is not limited to a single species, but occurs between many different groups of bacteria and algae (Sieburth, 1968; Bell \& Mrtchell, 1972; Bell et al., 1974). A correlation between the numbers of bacteria and algae has been found in many bodies of water (Overbeck, 1968, 1972; Schmidt, 1969, 1970; Jones, 1972; Gray, 1953). This is disputed, however, by GUNKEL (1968). Experiments in vitro with various green algae (Chlorella, Scenedesmus) showed that the growth of certain bacteria is enhanced by these algae, whereas other bacteria strains are clearly inhibited (VELA \& GUERRA, 1966; NiEw OLAK, 1971a, b).

If the stimulation of bacteria is a common phenomenon, just as widespread apparently is the antagonism between algae and bacteria. A complete and comprehensive review of the relationship - both mutualistic and antagonistic - between bluegreen algae and bacteria has been published by WhitTon (1973). SiebURTH (1964) compiled a list of all the marine algae species which are known to secrete antibacterial substances. Other studies on the antibacterial activity of marine algae have been made by Roos (1957), BurkHolder et al. (1960), Stebur th \& Pratt (1962), Sieburth (1968) and Mогкена \& CHu (1971). Secretion of bactericide substances by freshwater green 
algae has been found by Pratt et al. (1944), Vela \& Guerra (1966) and Niewolak $(1971 a, b)$.

From this review of the literature, it is clearly seen that the relationship between bacteria and algae is not a simple one. When the Schlei is considered as a study area, the situation becomes still more complicated. Rapid changes in the hydrographical conditions (e. g., salinity and temperature of the water) can cause fluctuations in the bacteria and algae numbers, which may have nothing to do with the bacteria-algae relationship itself. Furthermore, no studies were made as to the influence of grazing by zooplankton. These factors should be kept in mind when attempts are made to apply laboratory results to the situation in the Schlei.

When the phytoplankton and bacteria counts in the Schlei are compared, the maxima do not coincide. While large numbers of saprophytic bacteria accompany the spring Chlorella bloom, the saprophyte counts tend to decrease in the summer. This is particularly the case during the blue-green algae water bloom. Apart from the influence of various abiotic factors (see RHEINHEIMER, 1970e), the effect of the phytoplankton blooms on the distribution of the bacteria will be discussed, on the basis of the experimental results.

\section{Green algae-bacteria}

The large numbers of red bacteria in the spring and early summer are stimulated by the presence of Chlorella sp. These algae secrete extracellular organic substances which are utilized by the red bacteria, enabling them to compete with other heterotrophic bacteria in the Schlei. Since enhancement of the red bacteria begins at once in an actively growing Chlorella sp. culture, it is concluded that Chlorella secretes extracellular substances during the exponential phase of growth. These substances are therefore not autolysis or degradation products. The red bacteria are not predators on Chlorella. At no time were Chlorella cells colonized by bacteria, neither during the exponential nor stationary phases of algal growth.

Other strains of native Schlei bacteria tested were not significantly influenced in their development by the presence of Cblorella sp. in the culture medium. (A laboratory strain of $E$. coli was inhibited by Chlorella cultures, but only during the stationary growth phase of these algae.)

The unusually high saprophyte counts in the Schlei noted in the spring and summer of 1973 could also be partly due to extracellular products of Chlorella. Red pigmented bacteria often amounted to $30-40 \%$ of the total saprophyte numbers found during this time. The water bloom which occurred in the spring of 1973 was also more intense than usual; the concentration of Chlorella was far greater than in 1972 or 1974.

Studies on extracellular products of green algae show that these substances are many and varied. However, since among the bacteria tested only the red bacteria were noticeably enhanced by the presence of Chlorella, the substance(s) involved may not be of general use as a substrate to the majority of Schlei species. Glycollic acid is frequently mentioned as an extracellular product not only of Chlorella but also of other planktonic algae (FogG \& NALEWAJKO, 1964). It is not a popular substrate for 
bacteria, however. BERLAND et al. (1970) found that only one out of 25 marine bacteria species tested, a Pseudomonas, could utilize glycollate. Fogg \& Nalewajko (1964) state that LEWIN (unpublished) found several freshwater strains which "grow with this substance as sole carbon source". Although a knowledge of the nutritional requirements of the red bacteria is necessary before one can judge the importance of glycollic acid in their growth, tests have shown that these bacteria do grow better when glycollic acid is added to the culture medium under laboratory conditions (at a concentration of $1 \mathrm{~g}$ glycollic acid per 1 ).

\section{Blue-green algae and bacteria}

Since a filtrate of a unialgal Microcystis aeruginosa culture did not inhibit any of the bacteria tested, the growth of these bacteria is probably not suppressed by the Microcystis water bloom in the Schlei. The strains tested included relatively common brackish water bacteria isolated from the study area. It could be shown, however, that at least two bacteria strains associated with the Microcystis bloom inhibited the growth on agar plates of most bacteria tested. Both strains are white forms which develop rapidly at room temperature. In a culture filtrate of one of these strains, isolated from the Microcystis slime layer, all of the test bacteria were able to develop. Therefore the suppression on the agar plates is more likely due to a competition for nutrients within a limited area, rather than to any antibiotic substance.

Colonies on agar plates which are close to the inhibiting bacteria are smaller and paler than normal or may fail to develop entirely. The decrease in the saprophytic bacteria counts found in the Schlei during the summer months may, in fact, be partly due to competition with the white bacteria. It cannot be said with certainty, however, whether or not an actual suppression takes place in the open waters of the Schlei.

The question remains as to the relationship between the two inhibiting strains of bacteria (37 and 51 ) and Microcystis aeruginosa. It is possible that the frequent occurrence of strain 37 during a Microcystis bloom is only due to coincidence. The conditions favorable for the development of blue-green algae in late summer may also favor the growth of strain 37 (e. g., high temperature, alkaline milieu, nutrient supply) without there being a cause and effect relationship. On the other hand, blue-green algae and bacteria are so commonly found together that a symbiotic or mutualistic relationship may be taken as a fact. Of particular importance to heterotrophic bacteria are the extracellular organic substances secreted by algae. Among the blue-green algae in particular, the most common extracellular products are nitrogenous compounds (polypeprides, peptides and some amino acids) as described by WATANABE (1951), Fogg (1952), Fogg \& WestLake (1953) and WhitTon (1965). The slime layers of blue-green algae which are largely polysaccharide in nature (WoLK, 1973) also provide a substrate for many bacteria. It is therefore likely that strain 37 benefits from the extracellular products of $M$. aeruginosa, and for this reason is frequently found during the blue-green algae water bloom.

The same is probably true for strain 51 , which is found directly in and around the Microcystis slime layer. In addition to the algal extracellular products, other factors may also be involved in the distribution of these bacteria. It is possible that the 
bacteria have entered into a symbiotic relationship with Microcystis not only to receive organic matter but also for the $\mathrm{O}_{2}$ produced by the algae during photosynthesis (LANGE, 1971). In turn, $\mathrm{CO}_{2}$ is made available to the algae by bacterial assimilation of organic compounds. LANGE (1971) states that organic compounds assimilated by bacteria "may be one of the factors leading to algal bloom in lakes and ponds, especially when growth is not limited by the supply of phosphorus or other inorganic elements".

\section{SUMMARY}

1. Investigations were carried out on monthly voyages to the Schlei, a fjord of the western Baltic Sea, from 1972 to 1974.

2. The Schlei is characterized by two successive water blooms - one in the spring caused by Chlorella sp., and a Cyanophyceae bloom in late summer with Microcystis aeruginosa as the dominant species.

3. The blooms are accompanied by different bacteria populations. It was noted, e. g,, that the proportion of red pigmented bacteria is greatest during the spring, whereas in late summer the numbers of pigmented bacteria decrease and white or colorless forms dominate.

4. In order to determine the relationship of the bacteria to the phytoplankton blooms, the predominant algae and bacteria species in the Schlei were isolated, and laboratory experiments with these microorganisms were carried out.

5. The results of these experiments showed that the growth of the red bacteria was clearly enhanced when cultivated together with Cblorella sp.

6. The enhancement takes place immediately with actively growing Chlorella cultures. Apparently these algae secrete organic substances into the culture medium during their exponential phase of growth, which are utilized by the red bacteria. It is likely that a similar process occurs in the Schlei. The rapid increase in red bacteria has been shown to take place parallel to the development of the Cblorella water bloom in the spring. The proportion of pigmented bacteria decreases in the late summer with the breakdown of the Cblorella bloom, and a new bacterial population becomes dominant.

7. Other experiments with Chlorella sp. showed that Eschericbia coli is strongly inhibited by the presence of these algae. The inhibition takes place only after Cblorella has reached the end of the exponential phase of growth, however. The inhibitory substances are probably autolysis or degradation products which accumulate in the culture medium during the stationary phase of algal growth.

8. None of the bacteria tested had any influence on the growth rate of Chlorella sp., nor were the algae cells colonized by bacteria at any time.

9. With the development of the Microcystis bloom in late summer, white or colorless bacteria are more frequently found in the waters of the Schlei. At the same time, there is generally a decrease in the saprophyte counts including pigmented bacteria.

10. Two strains of white bacteria commonly associated with Microcystis were able to suppress the growth of many other bacteria on agar plates, especially red, yellow and brown pigmented species. 
11. Sterile filtrates prepared from the culture solutions of the white bacteria had no effect on the strains tested, however. The suppression on agar plates is therefore more likely due to competition for nutrients. There is no evidence that antibiotic substances are involved.

12. Filtrates prepared from non-axenic cultures of Microcystis aeruginosa during the exponential as well as stationary phase of growth also did not inhibit the growth of the bacteria tested.

13. The decrease in the numbers of saprophytic bacteria in the Schlei during the summer may be due in part to the presence of the large white colonies on agar plates which prevent other bacteria from developing. These white bacteria are apparently associated with Microcystis water blooms; possibly a symbiotic or mutualistic relationship exists between these microorganisms.

\section{LITERATURE CITED}

Ahrens, R., 1969. Okologische Untersuchungen an sternbildenden Agrobacterium-Arten aus der Ostsee. Kieler Meeresforsch. 25, 190-204.

Allen, M. M., 1968. Simple conditions for growth of unicellular blue-green algae on plates. J. Phycol. 4, 1-4.

BeLL, W. \& Mrtchell, R., 1972. Chemotactic and growth responses of marine bacteria to algal extracellular products. Biol. Bull. mar. biol. Lab., Woods Hole 143, 265-277.

- Lang, J. M. \& Mitchell, R., 1974. Selective stimulation of marine bacteria by algal extracellular products. Limnol. Oceanogr. 19, 833-839.

Berland, B. R., Bonin, D. J. \& Maestrini, S. Y., 1970. Study of bacteria associated with marine algae in culture. III. Organic substrates supporting growth. Mar. Biol. 5, 68-76.

Burkholder, P. R., Burkholder, L. M. \& Almodóvar, L. R., 1960. Antibiotic activity of some marine algae of Puerto Rico. Botanica mar. 2, 149-156.

FoGG, G. E., 1952. The production of extracellular nitrogenous substances by a blue-green alga. Proc. R. Soc. (B) 139, 372-397.

- \& Nalewajko, C., 1964. Glycollic acid as an extracellular product of phytoplankton. Verh. int. Verein. theor. angew. Limnol. 15, 806-810.

- \& WeSTLAKE, D. F., 1953. The importance of extracellular products of algae in freshwater. Verh. int. Verein. theor. angew. Limnol. 12, 219-232.

Grax, E. A., 1953. The microbiology of a polluted stream. Verh. int. Verein. theor. angew. Limnol. 12, 814-817.

Gunkel, W., 1968. Die Bakterien und ihre Beziehungen zum Plankton in den Tümpeln der Helgoländer Düne nach der schweren Sturmflut im Februar 1962. Mitt. int. Verein. theor. angew. Limnol. 14, 31-42.

JoNEs, J. G., 1972. Studies on freshwater bacteria: association with algae and alkaline phosphatase activity. J. Ecol. 60, 59-75.

KocH, W., 1965. Cyanophyceen Kulturen. Anreicherungs- und Isolierverfahren. Zbl. Bakt. Parasitkde (Abt. 1) Suppl. 1, 415-431.

KöNIG, D., 1970. Landschaftlid-ökologische Fakten und Abwasserbelastung. Kieler Meeresforsch. 26, 111-119.

LANGE, W, 1971. Enhancement of algal growth in Cyanophyta-bacteria systems by carbonaceous compounds. Can. J. Microbiol. 17, 303-314.

MEFFERT, M.-E., 1973. Einfluß von pH, COQ2-Konzentration und Bakterien auf das Wachstum der Blaualge Oscillatoria redekei vaN Goor. Arch. Hydrobiol. 72, 186-201.

MокквнA, S. N. \& CHu, G. W., 1971. Dermatitis-producing alga Lyngbya majuscula GomonT in Hawaii. II. Biological properties of the toxic factor. J. Phycol. 7, 8-13.

NELLEN, W. \& RhErNheimer, G., 1970. Einleitung und Literaturzusammenstellung früherer Arbeiten über die Schlei. Kieler Meeresforsch. 26, 105-109. 
Nrewolak, S., 1971a. The influence of living and dead cells of Chlorella vulgaris and Scenedesmus obliquus on aquatic microorganisms. Polskie Arch. Hydrobiol. 18 (1), 43-54.

- 1971b. The influence of alcohol extracts of some algae (Chlorella and Scenedesmus) on aquatic microorganisms. Polskie Arch. Hydrobiol, 18 (2), 31-42.

Overbeck, J., 1968. Prinzipielles zum Vorkommen der Bakterien im See. Mitt. int. Verein. theor. angew. Limnol. 14, 134-144.

- 1972. Distribution pattern of phytoplankton and bacteria, microbial decomposition of organic matter and bacterial production in eutrophic, stratified lake. In: Productivity problems of freshwaters (IBP-Unesco-Symposium). Ed. by Z. KayaK \& A. HillbrichTILkowska. Warszawa, 227-237.

Pratt, R., Daniels, T. C., Eller, J. J., Gunnison, J. B., Kumler, W. D., Oneto, J. F., Strait, L. A., Stoehr, H. A., Hardin, G. J., Milner, H, W., Smith J. H. C. \& Strain, H. H., 1944. Chlorellin, an antibacterial substance from Chlorella. Science, N. Y. 99, 351352.

Rheinheimer, G., 1970a. Sauerstoffhaushalt. Kieler Meeresforsch. 26, 126-128.

- 1970b. Ammoniak-, Nitrit-, Nitrat- und Phosphatgehalt. Kieler Meeresforsch. 26, 130-132.

- 1970c. Bakterienverteilung. Kieler Meeresforsch. 26, 150-156.

- 1970d. Colizahlen. Kieler Meeresforsch. 26, 156-159.

- 1970e. Einfluß verschiedener Faktoren auf die Bakterienflora. Kieler Meeresforsch. 26, 161168.

- 1970f. Hefen. Kieler Meeresforsch. 26, 179.

- 1971. Mikrobiologie der Gewässer. Fischer, Jena, 184 pp.

RIEPER, M., 1975. Investigations on the relationships between algal blooms and bacterial populations in the Schlei Fjord (western Baltic Sea). Diss., Kiel, 110 pp.

RodinA, A. G., 1972. Methods in aquatic microbiology. Univ. Park Press, Baltimore, $461 \mathrm{pp}$.

Roos, H., 1957. Untersuchungen über das Vorkommen antimikrobieller Substanzen in Meeresalgen. Kieler Meeresforsch. 13, 41-58.

Schiemann, S., 1974. Die Primärproduktion des Phytoplanktons der Schlei und des Windebyer Noors im Jahre 1972. Ein Vergleich von Methoden und Biotopen. Diss., Kiel, 173 pp.

Schmor, G. W., 1969. Vertical distribution of bacteria and algae in a tropical lake. Int. Revue ges. Hydrobiol. 54, 791-797.

- 1970. Numbers of bacteria and algae and their interrelations in some Amazonian waters. Amazoniana 2, 393-400.

Sieburth, J. MCN., 1964. Antibacterial substances produced by marine algae. Devs ind. Microbiol. 5, 124-134.

- 1968. The influence of algal antibiosis on the ecology of marine microorganisms. In: Adv. Microbiol. Sea 1, 63-94.

- \& PRATT, D. M., 1962. Anticoliform activity of sea water associated with the termination of Skeletonema costatum blooms. Trans. N. Y. Acad. Sci. (Ser. 2) 24, 498-501.

STAUB, R., 1961. Ernährungsphysiologisch-autökologische Untersuchungen an der planktischen Blaualge Oscillatoria rubescens DC. Schweiz. Z. Hydrol. 23, 82-198.

VELA, G. R. \& GueRRA, C. N., 1966. On the nature of mixed cultures of Chlorella pyrenoidosa TX 71105 and various bacteria. J. gen. Microbiol. 42, 123-131.

WatANABE, A., 1951. Production in cultural solution of some amino acids by the atmospheric nitrogen-fixing blue-green algae. Archs. Biochem. Biophys. 34, 50-55.

Whitron, B. A., 1965. Extracellular products of blue-green algae. J. gen. Microbiol. 40, 1-11.

- 1973. Interactions with other organisms. In: The biology of blue-green algae. Ed. by N. G. CARR \& B. A. Whitton. Blackwell, Oxford, 676 pp.

Wolx, C. P., 1973. Physiology and cytological chemistry of blue-green algae. Bact. Rev. 37, 32-101.

Author's address: Dr. Marianna Rieper

Biologische Anstalt Helgoland (Meeresstation)

D-2192 Helgoland

Federal Republic of Germany 